\title{
A GRANDE CRUZEIRO: A REGIÃO E A CIDADE A CIDADE E A REGIÃo - EXPERIÊNCIAS, NARRATIVAS E REFLEXÕES A PARTIR DE UM ESTUDO ETNOGRÁFICO
}

\author{
Ana Patrícia Barbosa ${ }^{1}$
}

Este ensaio fotográfico é resultado da pesquisa de doutorado ${ }^{2}$ realizada durante os anos de 2014 a 2017, na região da Grande Cruzeiro, em Porto Alegre, RS. Os encontros e reencontros com a Grande Cruzeiro iniciaram em 2014, nas caminhadas pelas ruas, pelos becos e vielas, na aproximação com os moradores, no olhar e escutar histórias de vida que atravessam temporalidades. Para a observação desses processos decorrentes da vida na metrópole, recorri a uma etnografia de rua, nos moldes propostos pelas antropólogas Ana Luiza Carvalho da Rocha e Cornelia Eckert (2013), as quais enfatizam como a pesquisa de campo é concretizada na cidade, por meio de caminhadas atentas, e da constante presença do etnógrafo no espaço da rua, compartilhando de um tempo vivido com os habitantes, e consecutivamente, desvendando os saberes e fazeres dos moradores da cidade.

Foi com essa intenção de adesão aos distintos territórios de minha pesquisa que procurei tecer meu percurso etnográfico na cidade de Porto Alegre e na região da Grande Cruzeiro, de forma a apreender as formas de ser e estar na cidade, especialmente dos grandes aglomerados urbanos. Essa experiência etnográfica, "na" e "da" cidade permite ao pesquisador ampliar seu olhar sobre as dinâmicas das interações cotidianas e representações sociais sobre o grupo estudado (ROCHA; ECKERT, 2013). Meu desafio inicial na pesquisa constituiu-se em descobrir e descobrir-me na região da Grande Cruzeiro, frequentar o cotidiano de seus moradores, suas ruas, seus becos e suas travessas, com seus hábitos e formas de ocupar o espaço urbano que, apesar de ser

\footnotetext{
${ }^{1}$ Universidade Luterana do Brasil, Brasil. Email: as.anapatricia@gmail.com ORCID id : https://orcid.org/0000-0002-1154-6047

2 Programa de Pós-Graduação em Diversidade Cultural e Inclusão Social da Universidade Feevale - Tese Defendida em 2017: Sobre Juventudes e Territorialidades: Estudo Etnográfico sobre as Trajetórias Juvenis na Grande Cruzeiro, em Porto Alegre/RS.
} 
geograficamente bem próximo ao centro da cidade, representa outro contexto de urbanidade, com características próprias a serem apreendidas.

As caminhadas pelos territórios da Grande Cruzeiro, inspiradas em uma etnografia de rua (Rocha; Eckert, 2013) constituíram-se num caminho inicial para remontar às memórias da paisagem urbana da Região e compreender as formas de interação social tecidas nas particularidades de habitar-se esse território da cidade de Porto Alegre. Cabe destacar, que esta aparente contradição de imagens da cidade, onde se acomodam diferentes formas do viver urbanos não pode ser analisada numa relação dicotômica de centro/periferia, mas sim como a possibilidade de refletir sobre a complexidade dos arranjos sociais (Rocha, 1995) no meio urbano e das formas da vida social (Simmel, 1987) que as práticas cotidianas dos habitantes das cidades conformam ao longo do tempo. Conforme Eckert e Rocha (2001: 109) "a cidade e suas possibilidades interpretativas derivam de sua condição de unidade de ação para uma comunidade urbana, uma vez que ela é, ao mesmo tempo, em múltiplos planos, expressão autoral de seus habitantes". Assim, comecei o meu processo de imersão na Grande Cruzeiro, desafiada a olhar e ver de novo, a olhar e perceber a Região como parte integrante da cidade, como expressão dos laços sociais que a constitui. Permiti-me exercitar deslocamentos, percorrendo ruas, becos, travessas, propondo-me a uma experiência de etnografia de rua.

Propondo-me a experiência de uma etnografia de rua, pude compreender a diversificação constitutiva do espaço urbano, perceptível numa tarefa cotidiana como andar de ônibus do centro da cidade à região da Grande Cruzeiro. Em meu trajeto até a Grande Cruzeiro foi possível perceber as características das geografias da desigualdade dessa Região em relação à cidade de Porto Alegre, que ganham visibilidade concreta aos meus olhos. A sensação de que a cidade deixa marcada em seu semblante o resultado das heterogeneidades sociais e das desigualdades que a compõe me acompanha durante o meu percurso, conforme apresento a seguir:

\section{DO CENTRO À PERIFERIA: POR UMA ETNOGRAFIA DE RUA NA/DA GRANDE CRUZEIRO}


Foto 1: Esquina Rua José do Patrocínio e Avenida Venâncio Aires

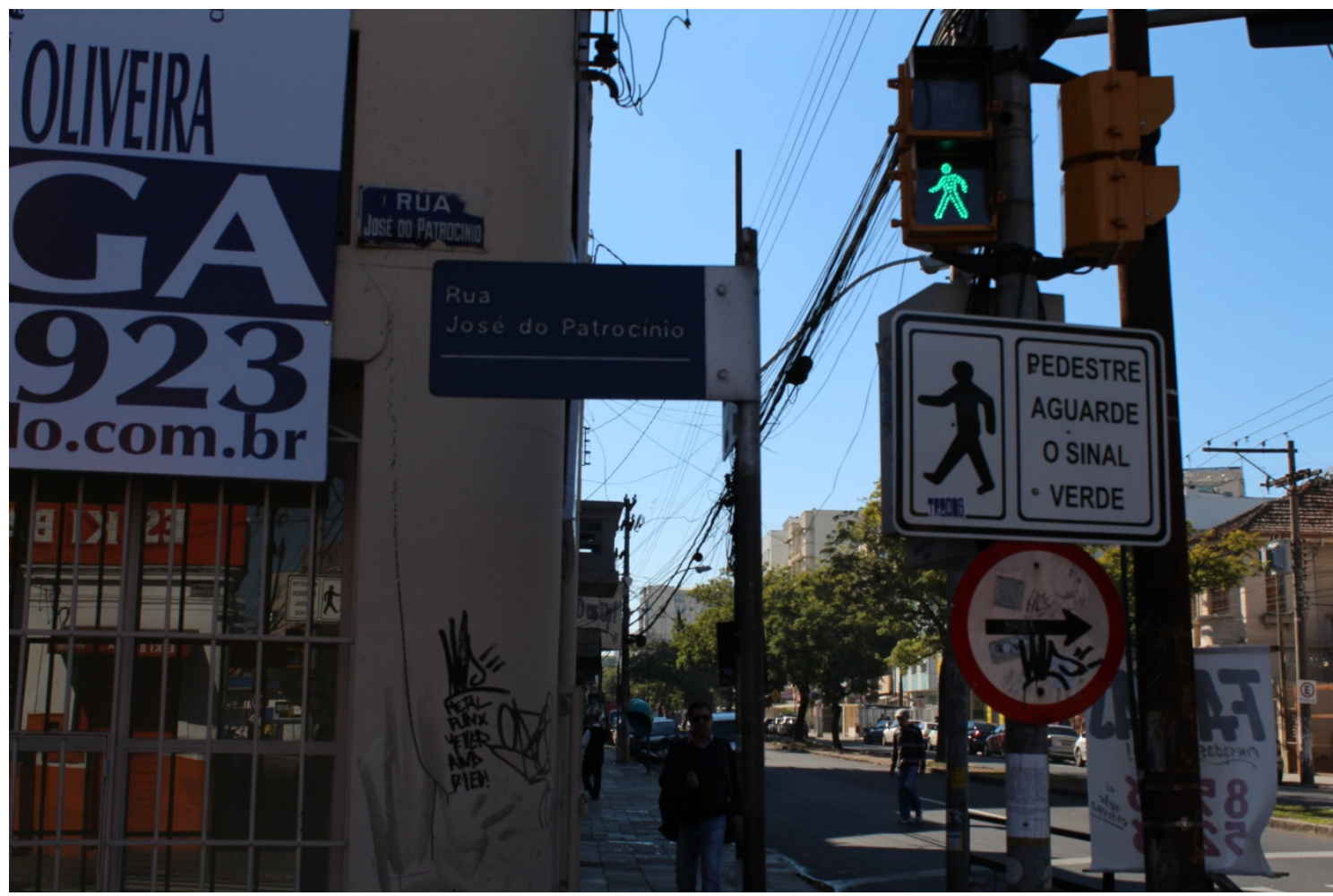

Fonte: Acervo Pessoal

Foto 2: Ponto de ônibus Rua José do Patrocínio

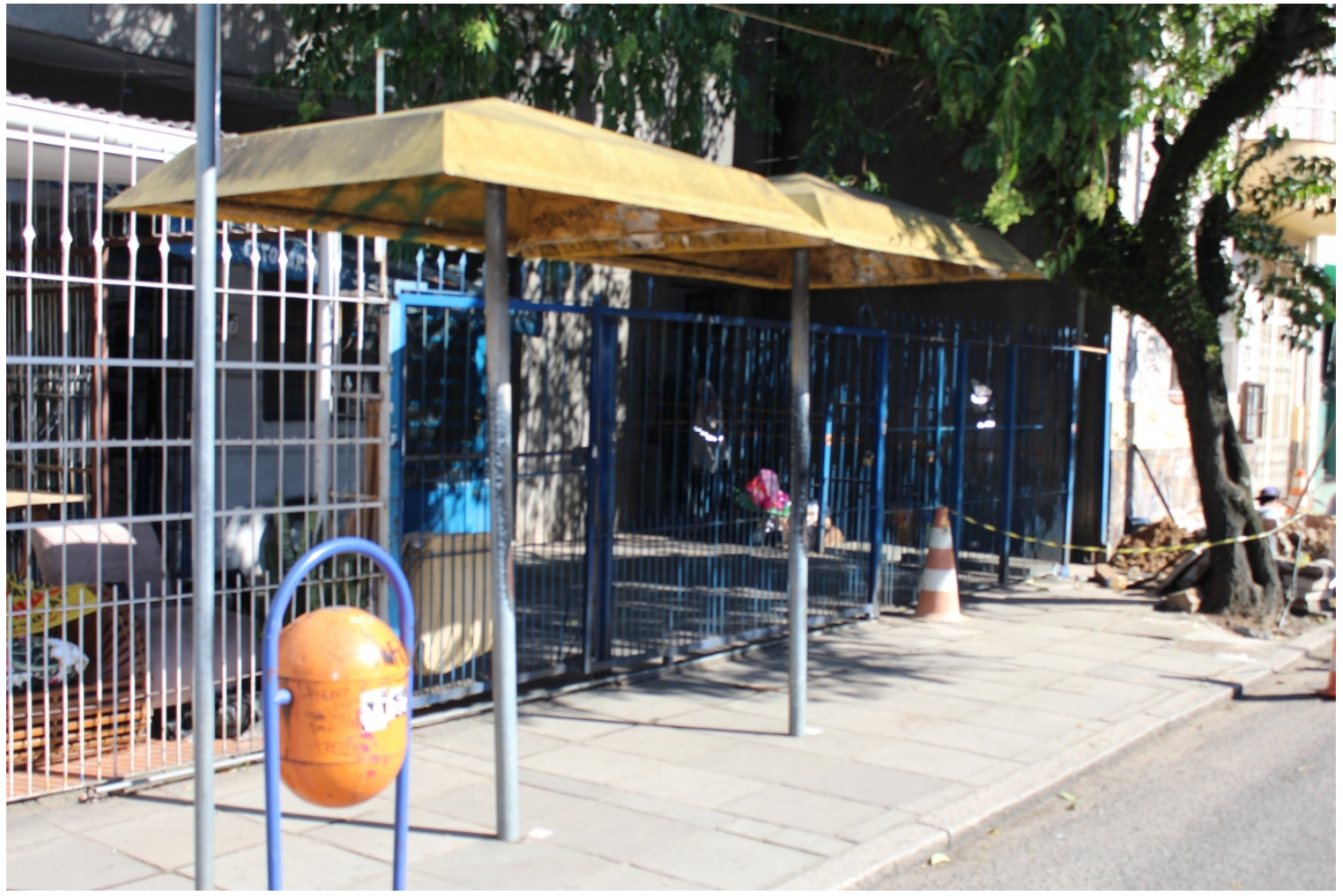

Fonte: Acervo Pessoal

Foto 3: Avenida João Pessoa em direção ao bairro Azenha 


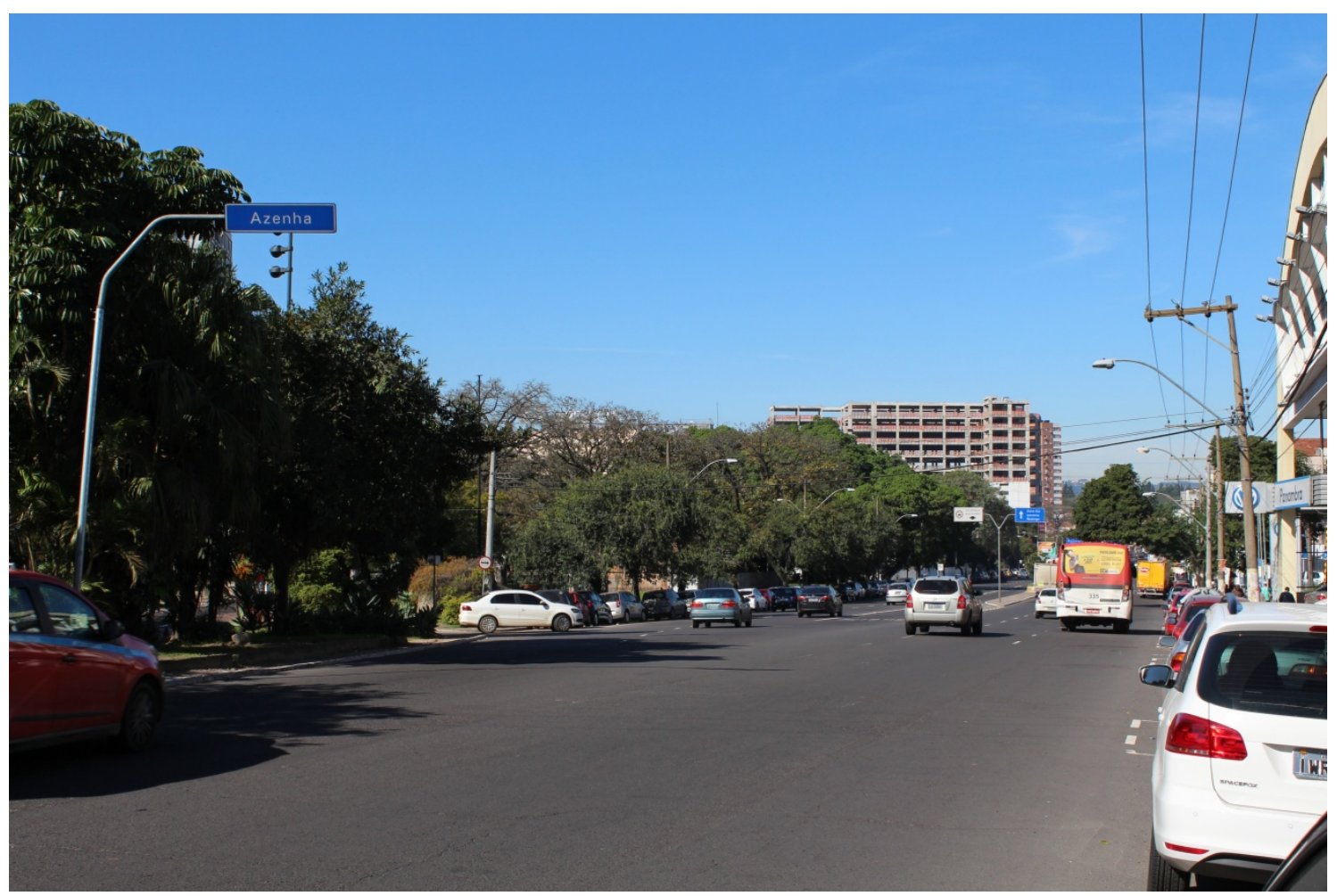

Fonte: Acervo Pessoal

Foto 4: Final da Avenida Azenha em direção a Avenida Dr. Carlos Barbosa

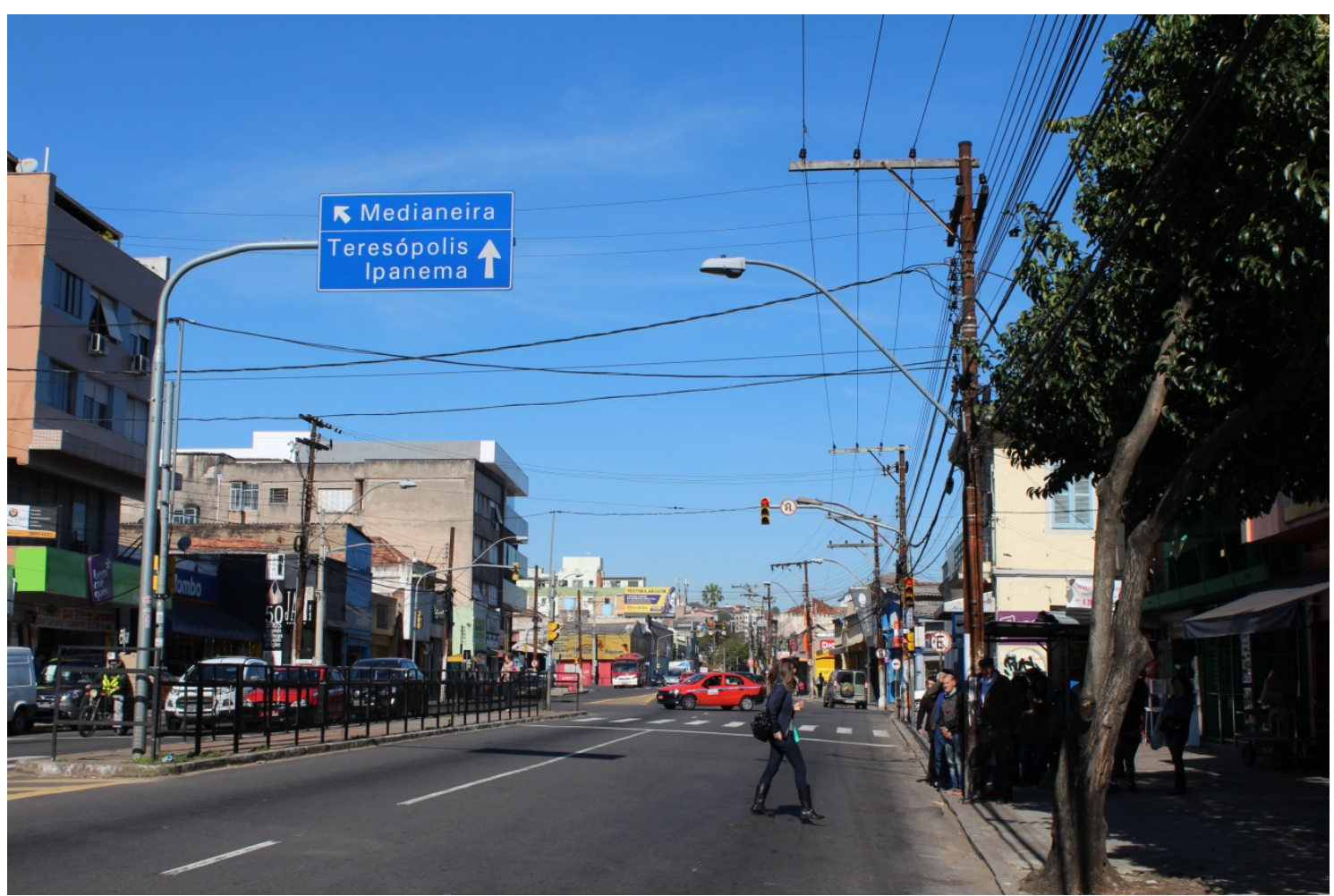

Fonte: Acervo Pessoal 
Foto 5: Final da Avenida Dr. Carlos Barbosa

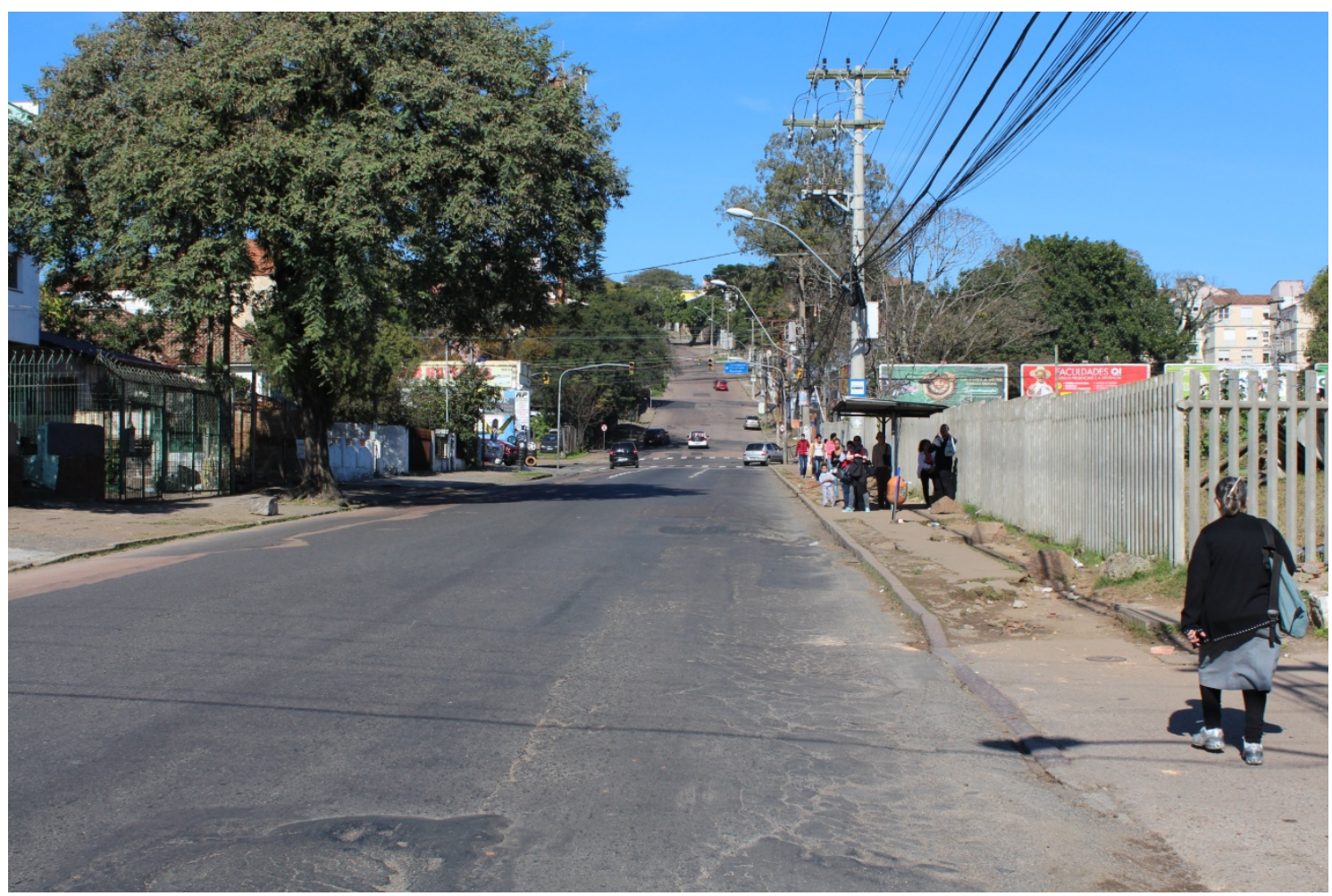

Fonte: Acervo Pessoal

Foto 6: Avenida Dr. Carlos Barbosa esquina Avenida Moab Caldas

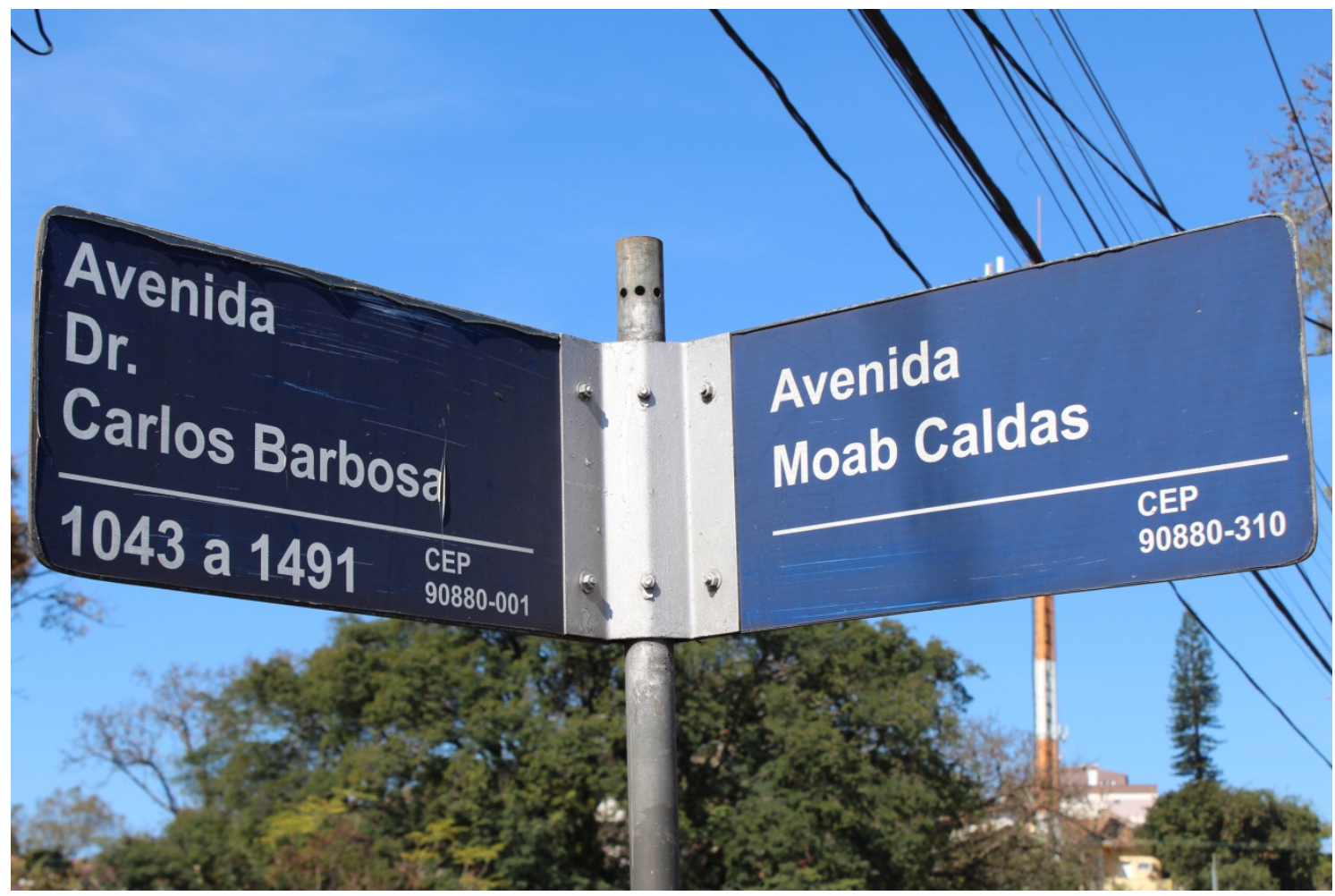

Fonte: Acervo Pessoal 
Foto 7: Início Avenida Moab Caldas

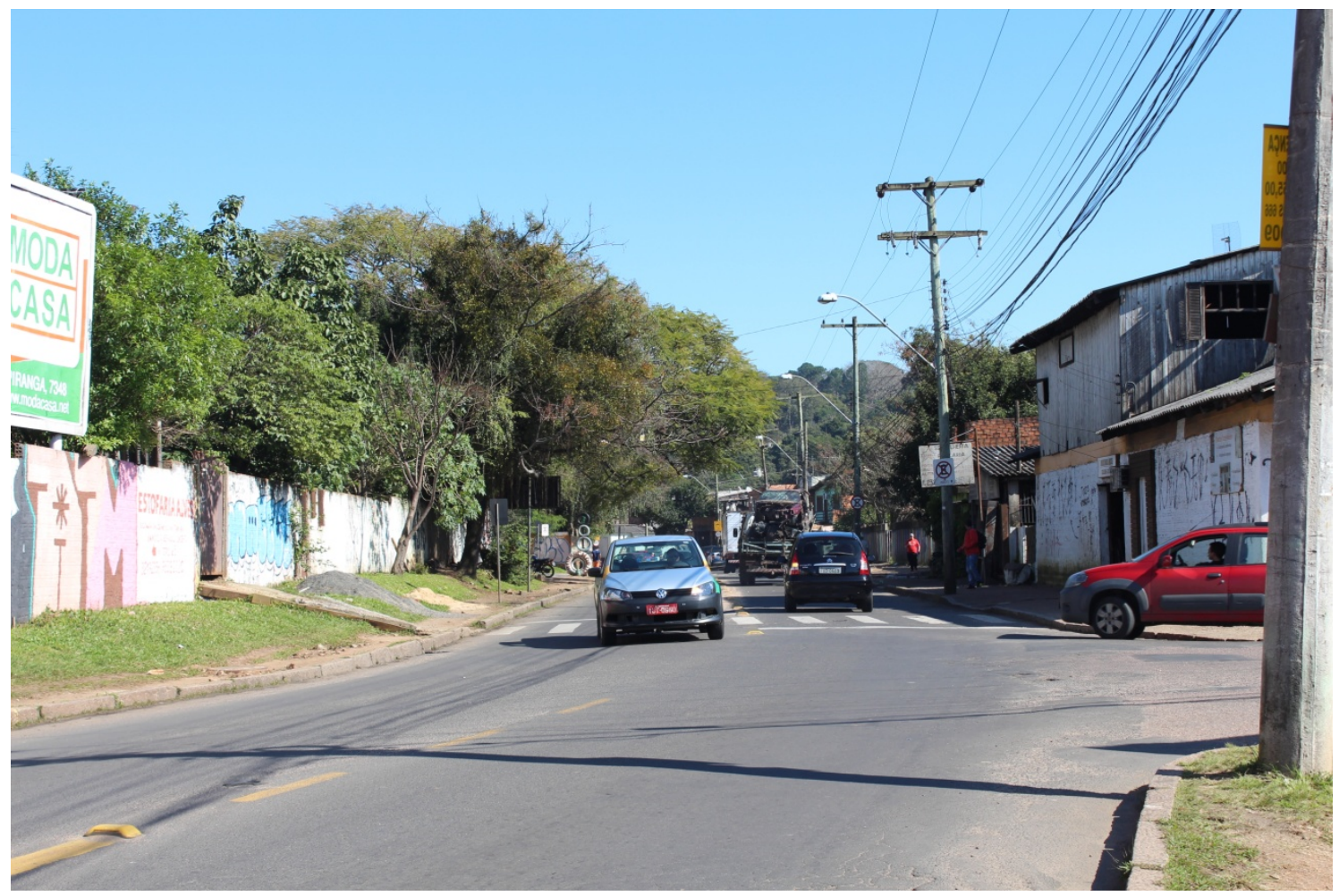

Fonte: Acervo Pessoal

Foto 8: Trecho Avenida Moab Caldas

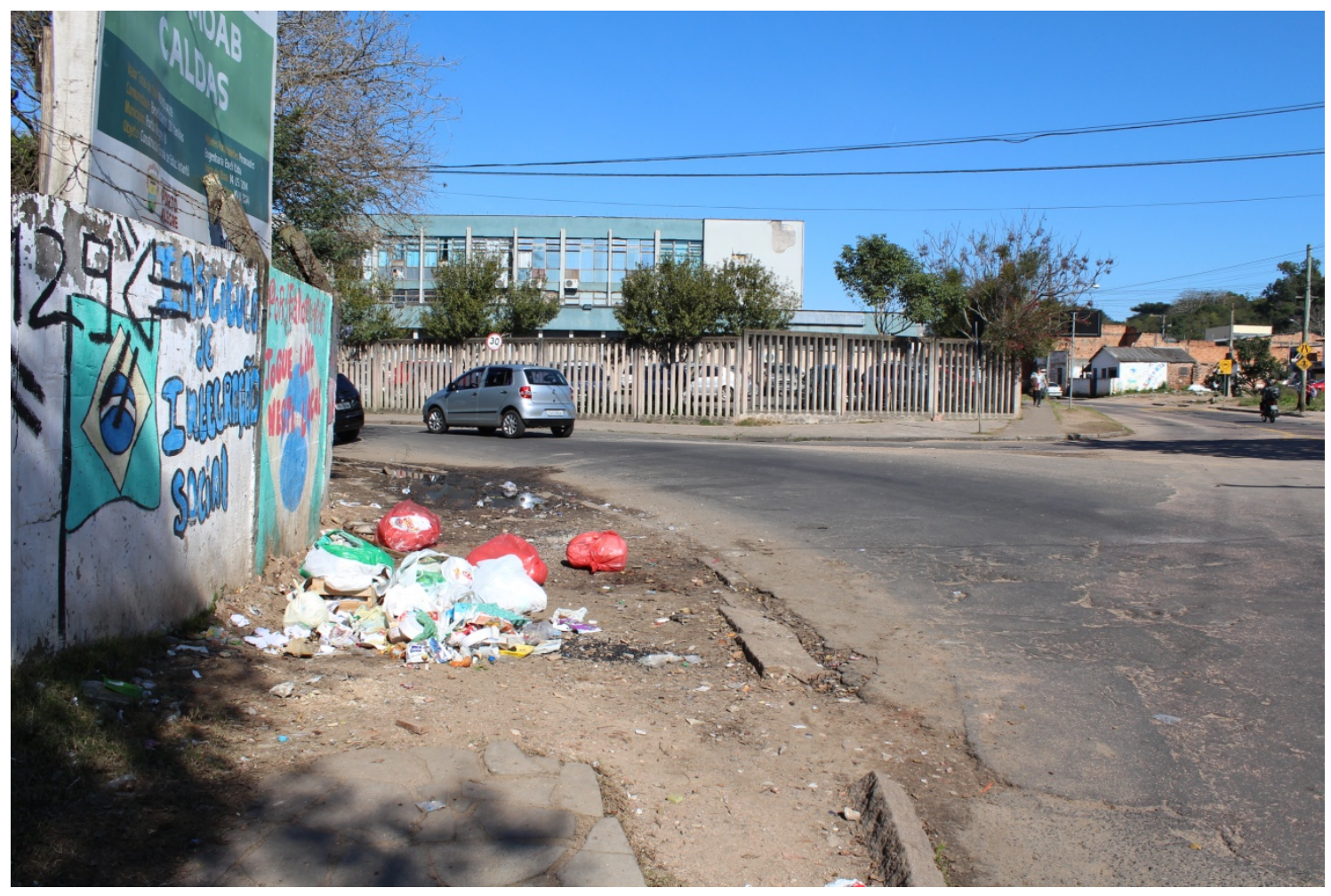

Fonte: Acervo Pessoal

Iluminuras, Porto Alegre, v. 21, n. 54, p. 849-861, setembro, 2020. 


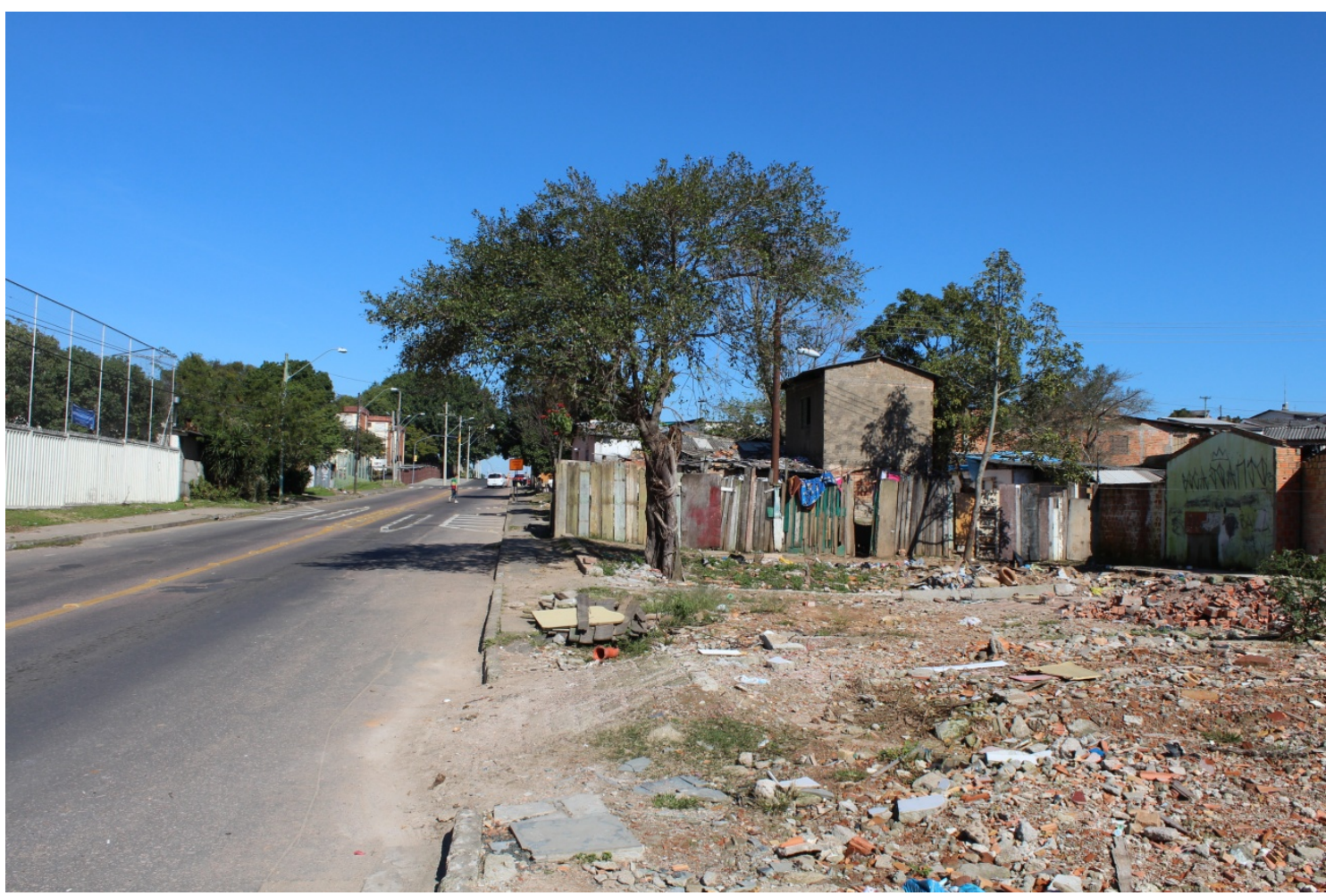

Fonte: Acervo Pessoal

Foto 10: Trecho Avenida Moab Caldas

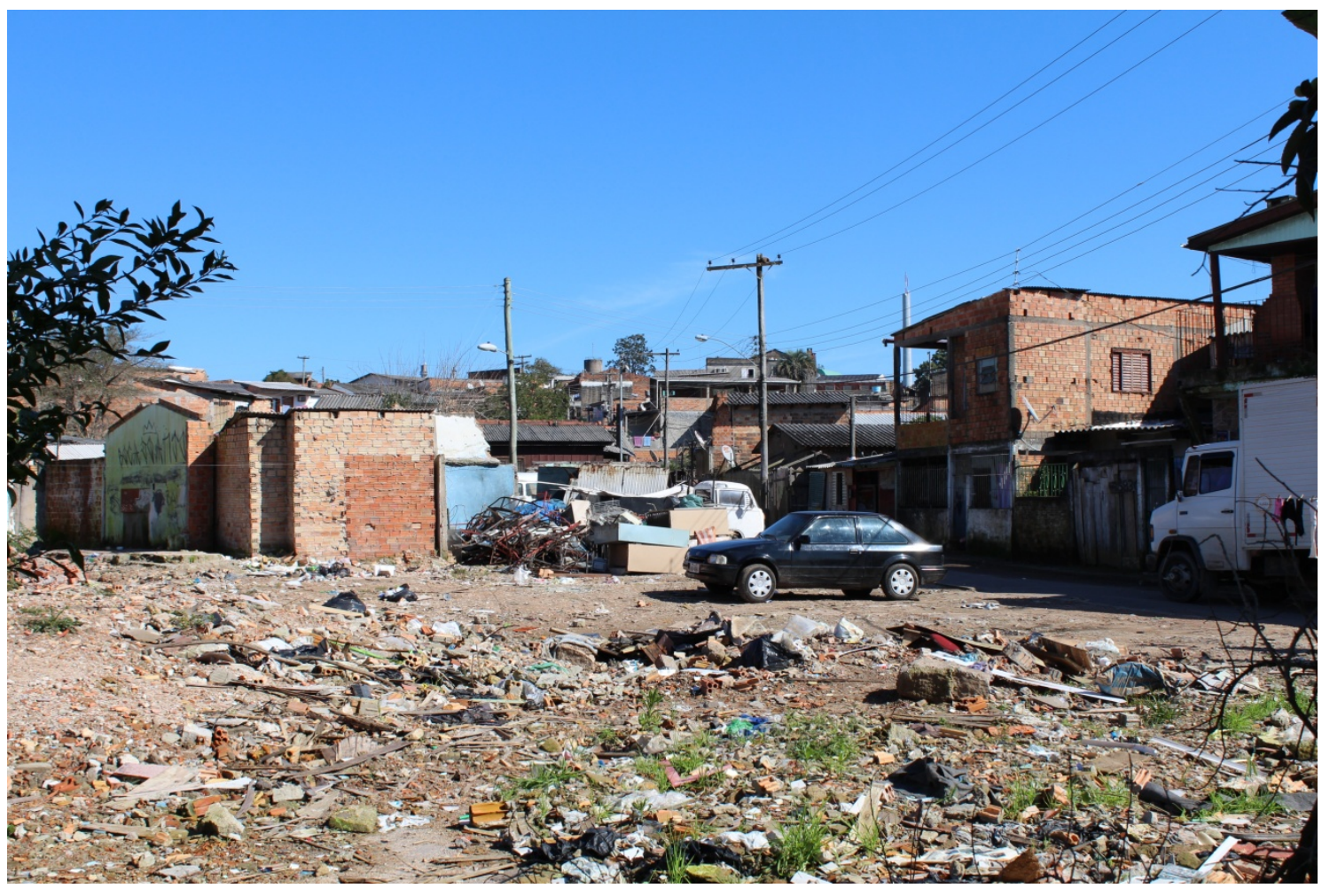

Fonte: Acervo Pessoal

Iluminuras, Porto Alegre, v. 21, n. 54, p. 849-861, setembro, 2020. 
Foto 11: Trecho Avenida Moab Caldas

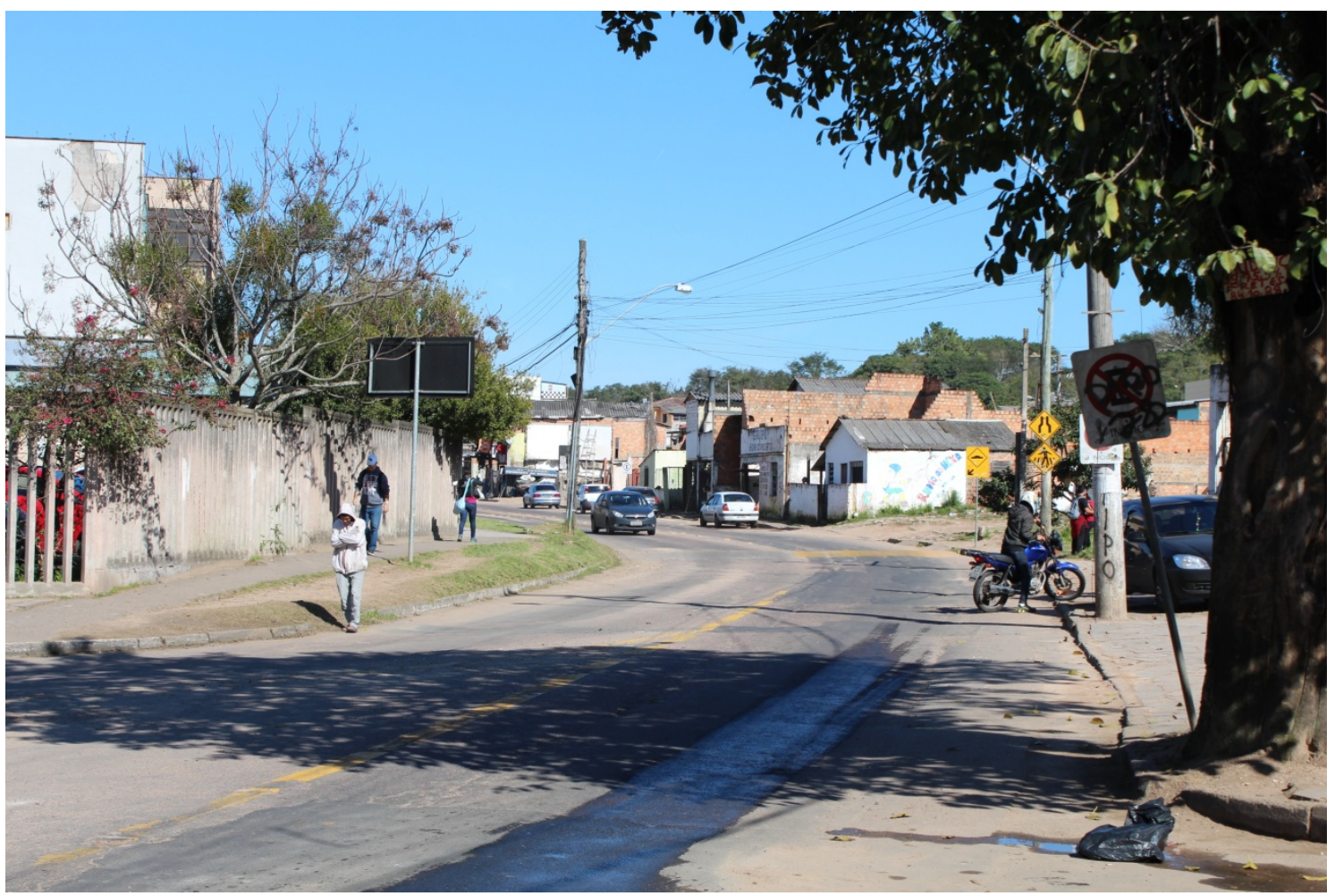

Fonte: Acervo Pessoal

Foto 12: Ponto Final do Ônibus Avenida Cruzeiro

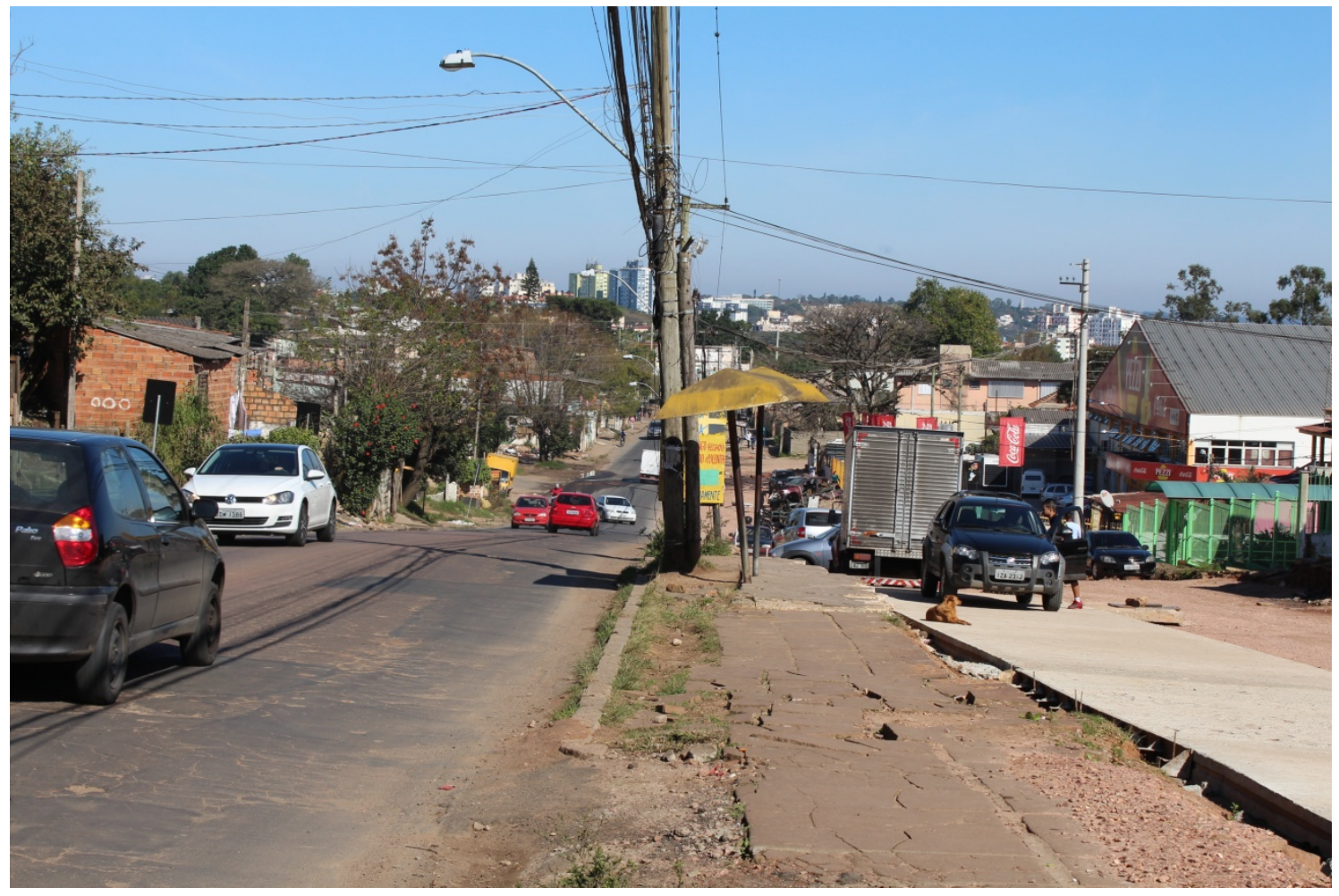

Fonte: Acervo Pessoal 
Foto 13: Trecho Avenida Cruzeiro

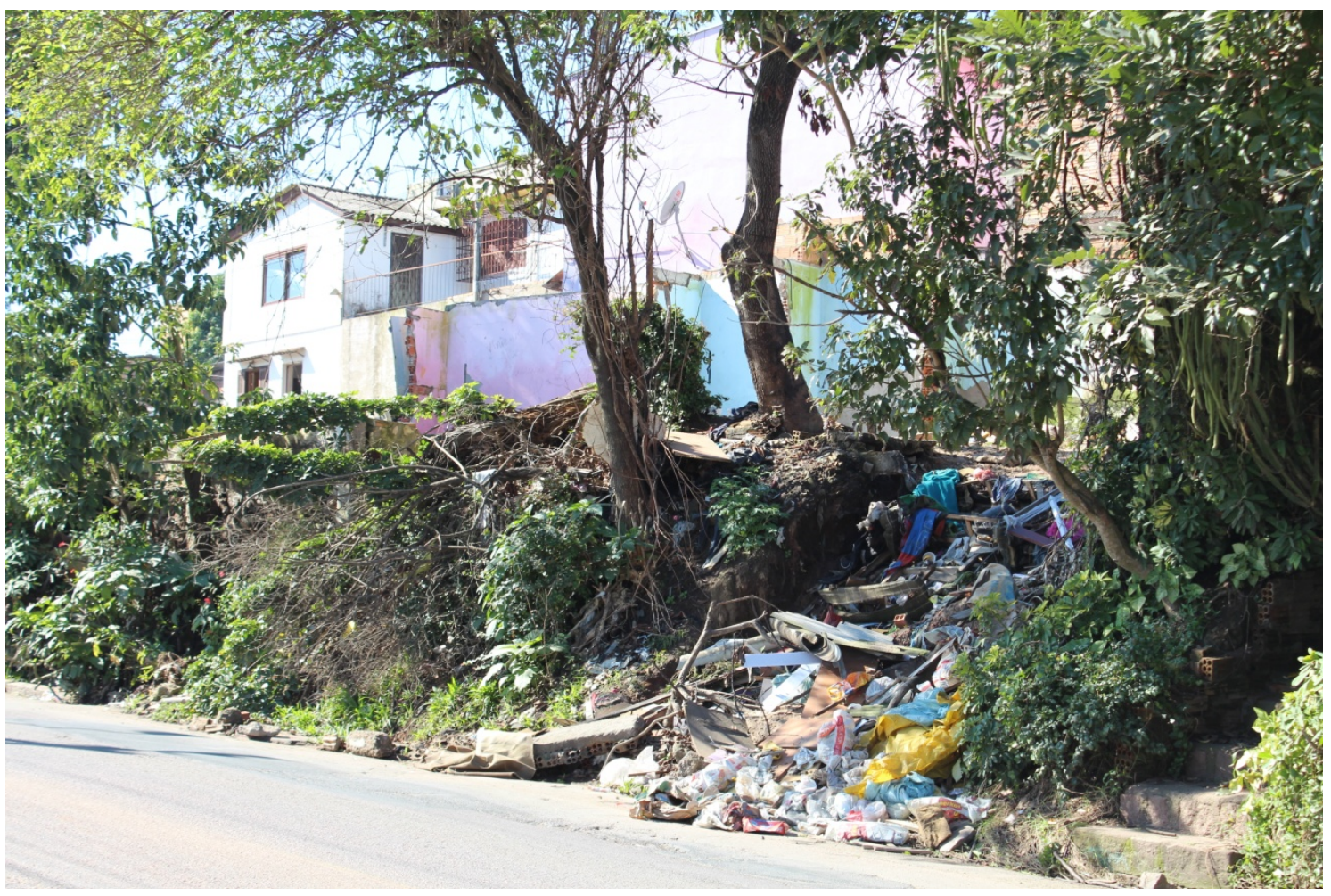

Fonte: Acervo Pessoal

Foto 14: Trecho Avenida Cruzeiro

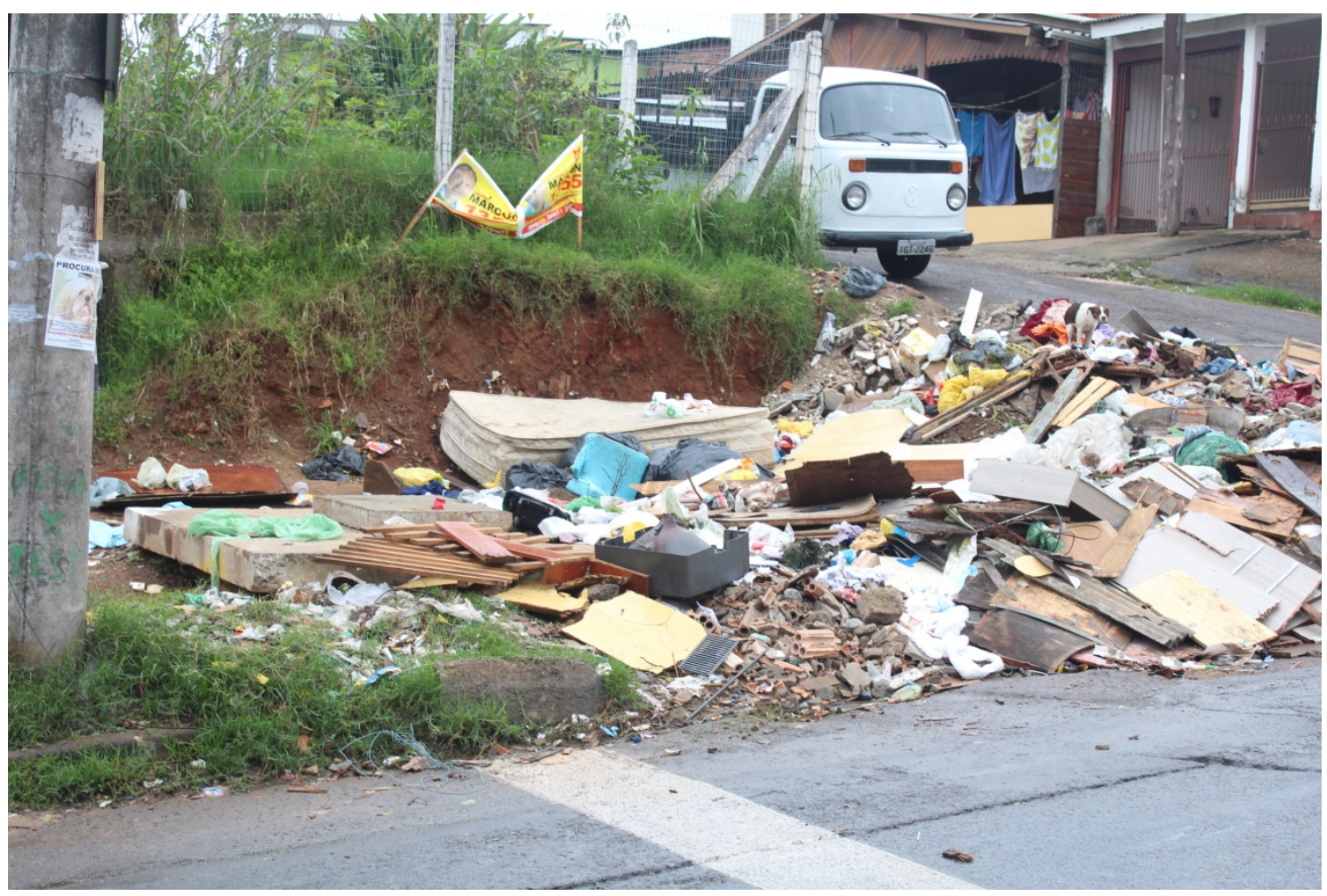

Fonte: Acervo Pessoal

Iluminuras, Porto Alegre, v. 21, n. 54, p. 849-861, setembro, 2020. 
Foto 15: Esquina Avenida Cruzeiro com Rua Dona Otília

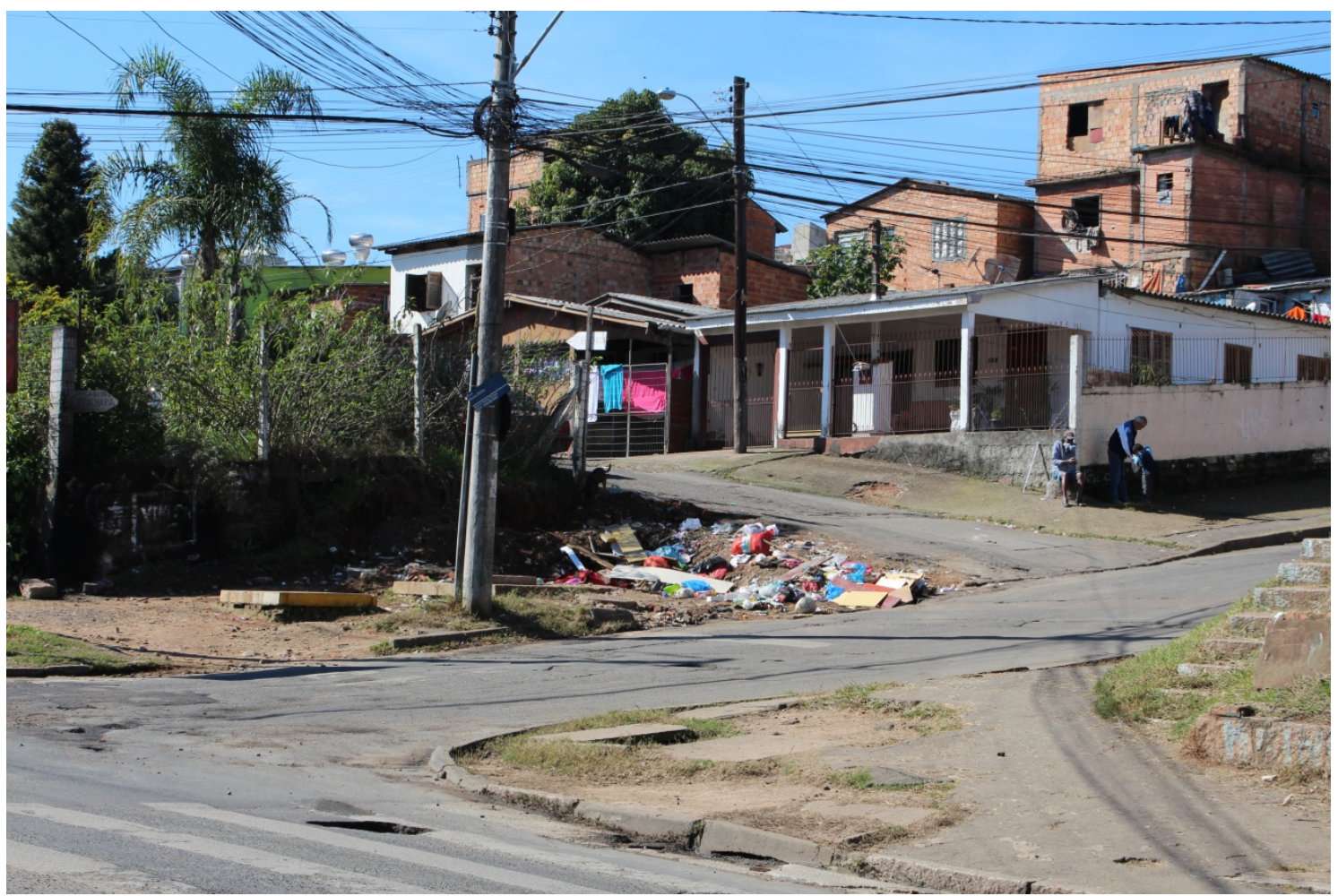

Fonte: Acervo Pessoal

Foto 16: Rua Dona Otília - acesso vila Barracão e Vila Cruzeiro do Sul

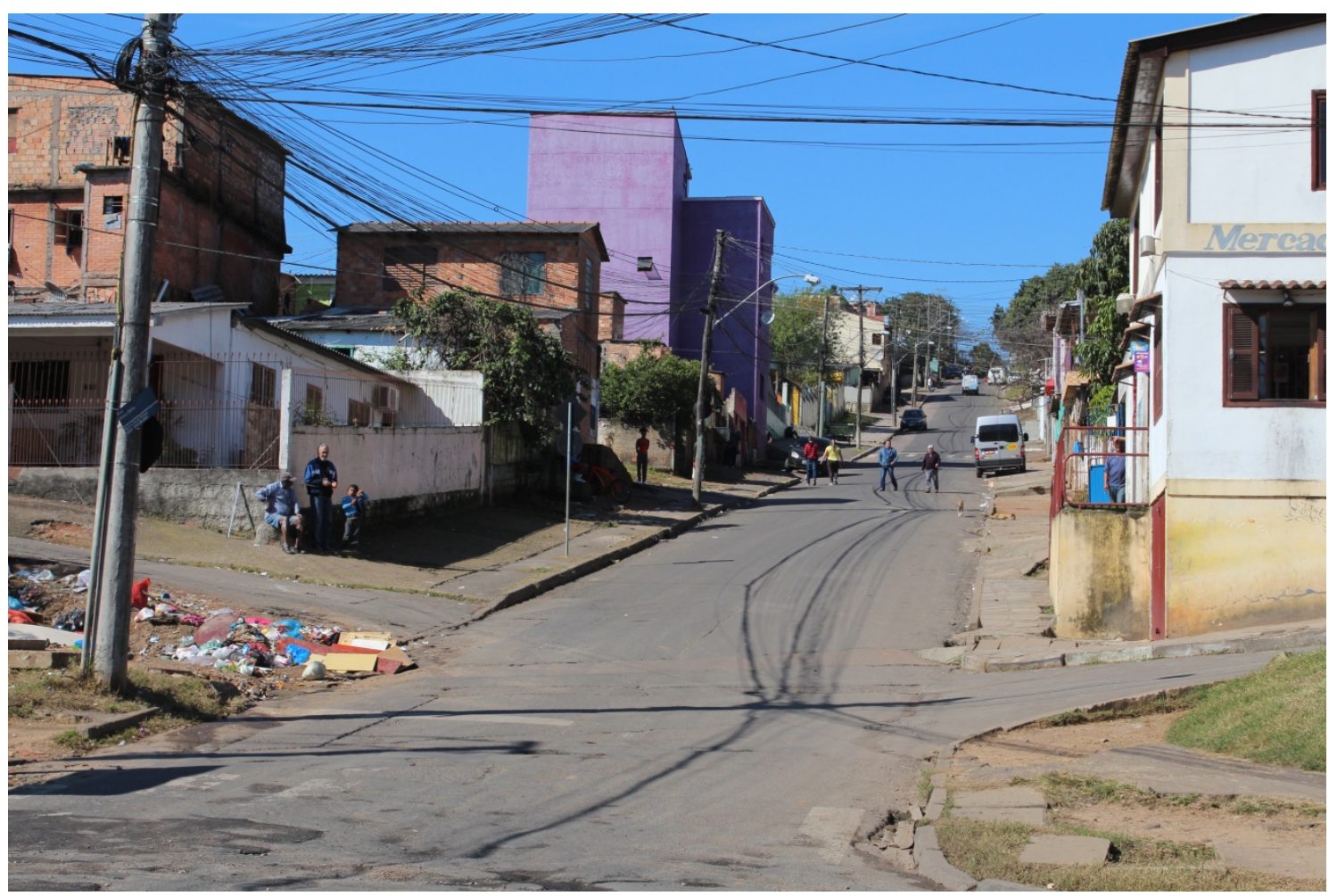

Fonte: Acervo Pessoal 
Foto 17: Esquina Rua Dona Otília com Travessa B

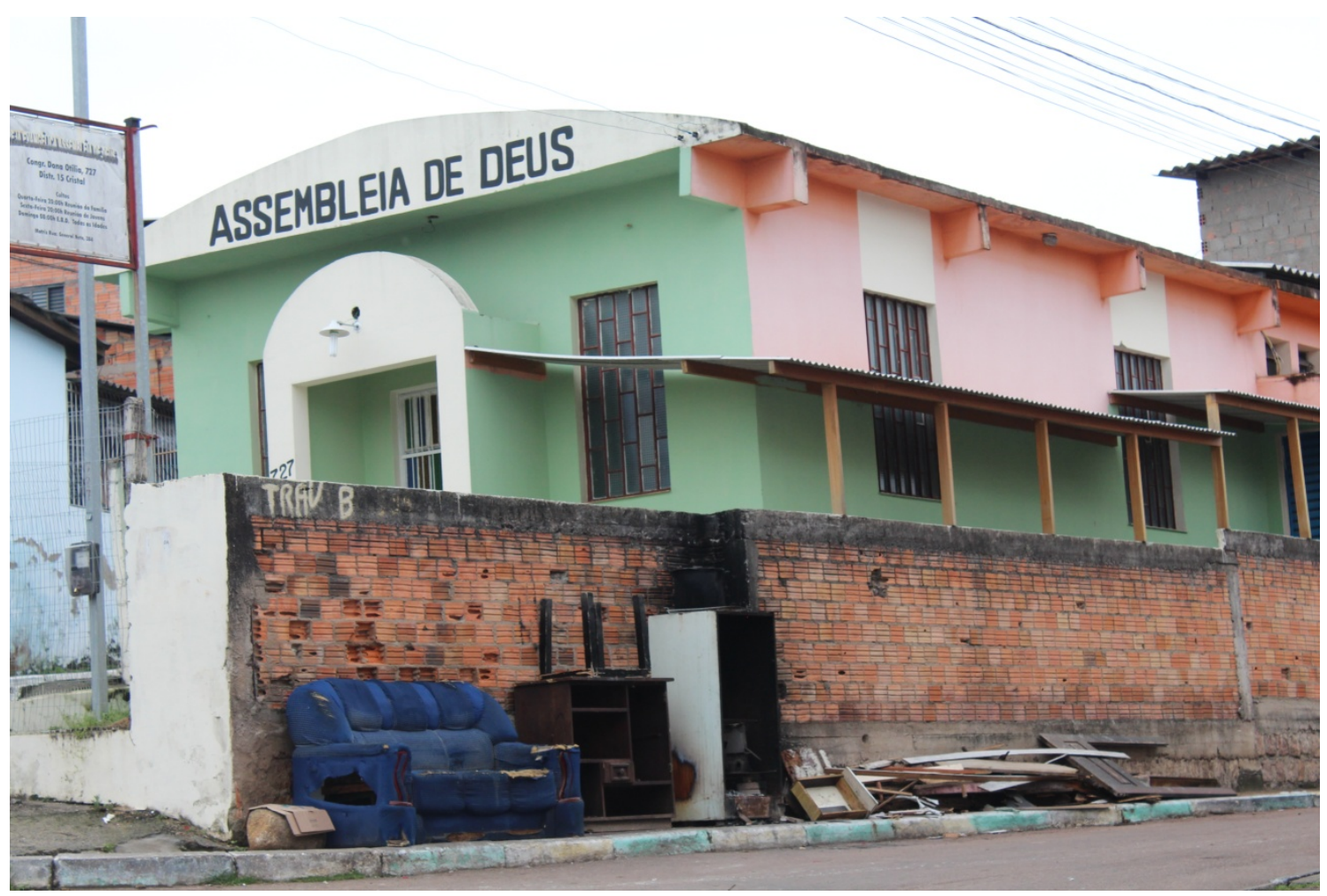

Fonte: Acervo Pessoal

Foto 18: Trecho Travessa B

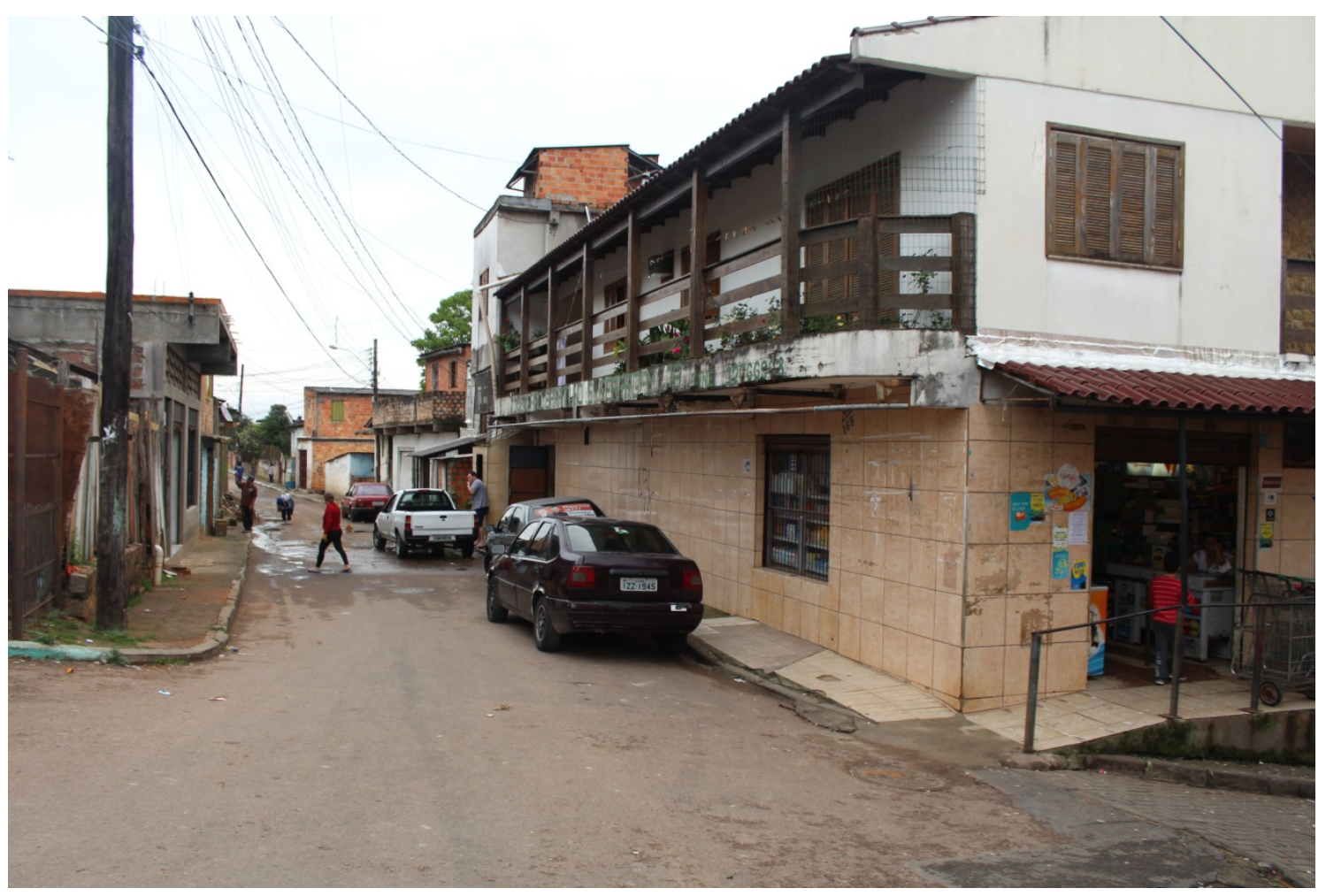

Fonte: Acervo Pessoal 
Foto 19: Trecho Travessa B

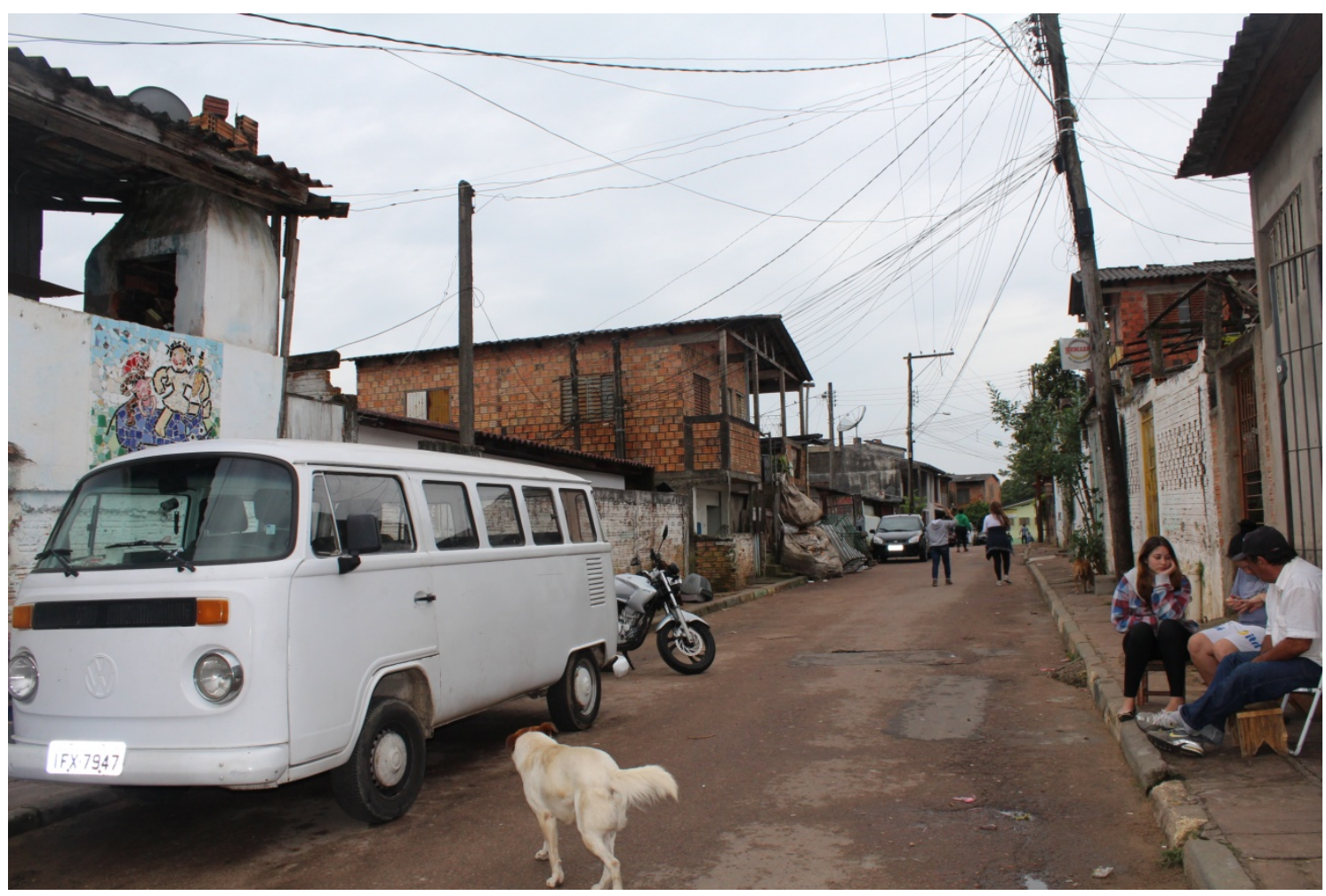

Fonte: Acervo Pessoal

Foto 20: Trecho Travessa $B$

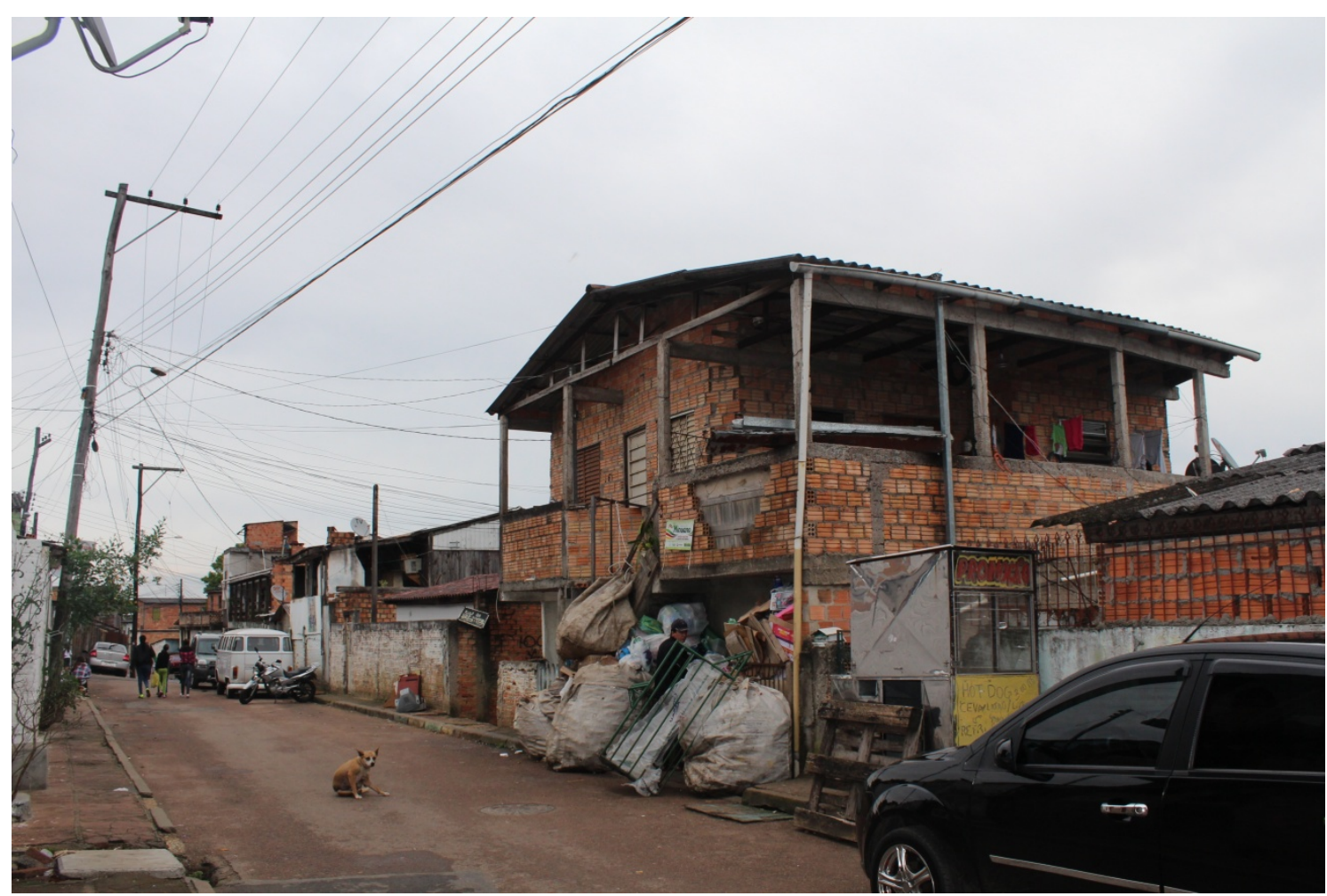

Fonte: Acervo Pessoal 


\section{REFERÊNCIAS}

ANDRADE, Rosane de. Fotografia e Antropologia: Olhares Fora-Dentro, São Paulo: Estação Liberdade, 2002.

DE CERTEAU, Michel. A invenção do cotidiano. Petrópolis, RJ: Vozes, 2012.

ECKERT, Cornelia; ROCHA, Ana Luiza Carvalho da. Etnografia de rua: estudos de antropologia urbana. Porto Alegre: Editora da UFRGS, 2013.

ECKERT, Cornelia; ROCHA, Ana Luiza Carvalho da. Premissas para o estudo da memória coletiva no mundo urbano contemporâneo sob a ótica dos itinerários urbanos e suas formas de sociabilidade. Iluminuras: Série do Banco de Imagens e Efeitos Visuais, Vol. 2, $\mathrm{n}^{\mathrm{o}}$ 4. Porto Alegre: Banco de Imagens e Efeitos Visuais, PPGAS/UFRGS, 2001.

ECKERT, Cornelia; ROCHA, Ana Luiza Carvalho da. Etnografia: saberes e práticas. Iluminuras Revista Eletrônica do BIEV/PPGAS/UFRGS, v. 31, p. 1, 2008.

SIMMEL, Georg. A metrópole e a vida mental. In: VELHO, Otávio (Org) O fenômeno urbano. Rio de Janeiro, Editora Guanabara, 1987.

Recebido: 22/08/2020

Aprovado: 04/09/2020 